\title{
Knowledge-Based \\ Development in Small Communities - Efficient Management Based on Local Expertize
}

\author{
Cristian Teodorescu, Lucian Constantin, \\ Margareta Nicolau, Aurelia Ballo and Cristiana Cosma
}

Additional information is available at the end of the chapter

http://dx.doi.org/10.5772/47437

\section{Introduction}

The "Lisbon Strategy" was adopted in 2000 by EU countries as a response to the challenges of globalisation and ageing. It set the strategic goal for EU "to become the most dynamic and competitive knowledge-based economy in the world by 2010, capable of sustainable economic growth with more and better jobs and greater social cohesion and respect for the environment" [1]. As the deadline approached, it became clearer that the above strategic goal will not be attained and the Strategy as a whole will be a failure. The main findings of a thorough analysis of this failure, carried out by EU officials were, among others [2]:

- $\quad$ The Lisbon Strategy has helped build broad consensus on the reforms that the EU needs and generated mutually acceptable solutions, still waiting to be implemented;

- It is not always possible to demonstrate a causal link between Lisbon reforms and EU economic growth and jobs outcomes, in the period 2000-2010. These results would be probably the same, without having a "Lisbon Strategy";

- The strategy should have been organised better to focus more on critical elements which played a key role in the origin of the economic crisis (risk in financial markets, speculative housing markets, credit-driven consumerism, wage increases outpacing productivity gains);

- The delivery gap between strategy commitments and actions has not been closed;

- Communication, awareness and public support for the objectives of the Strategy remained weak at EU and at national level;

- The non-binding character of the Lisbon Strategy contributed to its failure, and this lesson needed to be taken into account by the new Europe 2020 strategy. 
The main idea emerging from the above remarks is that the Lisbon Strategy has failed not because of its generous, munificent objectives but because of inadequate operational implementation, lack of organizational measures and reforms, hesitation to generate and accept new solutions to the new challenges of globalization and economic crisis.

EU is now on the way to implement a new 10-year strategy, the "Europe 2020" [3].

There are three main priorities in the new EU targets for 2020:

- Smart growth: developing an economy based on knowledge and innovation. Again, the role of knowledge is the most important;

- Sustainable growth: promoting a more resource-efficient, greener and more competitive economy;

- Inclusive growth: fostering a high-employment economy delivering social and territorial cohesion.

In trying to give a substantial answer to the simple question: "where does EU want to be by 2020?" the European Commission proposes the following headline targets for 2020:

- $\quad 75 \%$ of the population aged 20-64 should be employed;

- $\quad 3 \%$ of the EU's GDP should be invested in R\&D;

- $\quad$ The "20/20/20" climate/energy targets should be met;

- $\quad$ Early school leavers should represent under 10\% ;

- $\quad$ At least $40 \%$ of the younger generation should have a tertiary degree;

- 20 million less people should be at risk of poverty.

- The Commission proposes that EU goals are translated into national targets and trajectories that should become binding, one way or another for the Member Countries.

- There are seven flagship initiatives to catalyze progress under each priority theme:

- "Innovation Union" to improve framework conditions for research and innovation;

- $\quad$ "Youth on the move" to facilitate the entry of young people to the labour market;

- $\quad$ "A digital agenda for Europe" to speed up the roll-out of high-speed internet;

- $\quad$ "Resource efficient Europe" to help decouple economic growth from the use of resources;

- $\quad$ "An industrial policy for the globalization era" to improve the business environment, notably for SMEs;

- $\quad$ "An agenda for new skills and jobs" to modernise labour markets and empower people;

- $\quad$ "European platform against poverty".

Though these intentions show that the future instruments meant to implement the Europe 2020 Strategy may be better structured than those accompanying the Lisbon Strategy, they are mainly regarding the actions to be carried out at EU central level and by Member States. The approach for implementing the new strategy does not differ much from the Lisbon Strategy operational implementation: framing the general action plans by the Commission and asking Member States to take measures they believe appropriate, in line with the actions set up by the Commission. This is essentially a top-down, ex-cathedra, approach that may work when it is about labelling products, eliminating food additives, limiting the use of some pesticides, setting up new standards for the TV broadcasting but it certainly will not 
work when it comes to real people, to apply unavoidable austerity measures, to changing mentalities and modify habits in a 10-year interval, etc. Such an approach will probably encourage bureaucracy and corruption, asking for larger spending (from the money provided by the EU tax-payers) to prevent such consequences.

The present study recognizes and accepts the high-value of the general objectives included in the Europe 2020 Strategy but presents a case of a possible bottom-up approach in building of a knowledge-based EU, starting from the lower level, of rural communities. It presents the results of a Pilot Project carried out in the period 2009-2011 in a small rural area of Romania, in the Suceava County. The Project was led by the Romanian National R\&D Institute for Industrial Ecology (INCD-ECOIND, Bucharest) that provided the facilitators, experts, laboratory infrastructure, background information.

The main lines of the present work are:

1. Identifying the driving forces for the Project and their particularities for Romania;

2. Defining essential concepts (development vs. growth);

3. A discussion of the sources of sustainable knowledge-based development;

4. Detailing the approach for implementing elements of knowledge-based development in the selected focal area: how to evaluate, mobilize and articulate the local expertize and energies to contribute to the Project;

5. Description of main results of the Project in 2 Projects addressing energy and environmental issues in the focal area.

The literature in the field is huge but it deals mainly with recognized centres of knowledge (urban environment where the intellectual capital is concentrated) and with knowledgebased development metrics [4-9]. Both aspects are important: the first, because it may illustrate more rapidly the benefits and the limits of knowledge-based development there where the intellectual capital is more active and reacts more swiftly, the second because knowledge-based development management does not have its recognized metrics, which is an absolutely essential tool to assess the correctness of the approach. Measuring, comparing knowledge and making decisions in these circumstances is difficult because the intangible, weightless character of knowledge [10,12].

Though not as spectacular as new inventions or breathtaking discoveries, the Project demonstrates that there is an important amount of latent knowledge and expertise in small communities that could contribute, even in the short term, to the well-being of local people. It is important to create a friendly environment for dialogue and communication, to involve local people to the decision making process, to build on their ideas and perception, to generate communities of practice. This knowledge is not necessarily about advanced physics or nanotechnologies but can generate satisfaction and well-being, can contribute to a better life of communities.

\section{Driving forces for the project}

Aligning the Romanian society to the quality of life standards of other EU members requires much more than a bunch of legal norms, much more than Agencies and Commissions for 
Development, Sustainability, Human Rights, Environment, Social Inclusions, etc., even if these institutions have a role to play and are aligned to the EU legal system, Agencies and Commissions.

Europe 2020 will succeed if and only if its advantages will reach, in the short term, every level of the society, if and only if every small community and its members will be convinced to act along the Europe 2020 objectives because they will be the first and most important beneficiaries.

What the Lisbon Strategy and the Europe 2020 lack is to stress that implementation calls for dedicated specialists not staying at a desk, setting up questionnaires, action plans, producing tons of deliverables and intensively using the internet capabilities but going down, innovating and generating new approaches for communicating, convincing, campaigning, working with people, understanding their needs, building on what they already have, respecting them, fighting bureaucracy, inertia, poverty. The Europe 2020 will be a success only if it will be more than a Strategy but a Crusade against poverty and exclusion.

In general for the Eastern Europe and in particular for Romania, now included in the EU, the last 50 year history presents a heavy legacy.

In its earliest stage, the Communist Regime destroyed the traditional social structures that proved their value and sustainability for centuries; it levelled the society and replaced old structures by central planning and governance. Small communities had not had to think taking initiatives was considered insidious. They simply had to wait from the Central Government and from the Communist Party structures (the only legitimate depositaries of what is good and necessary) what they have to do. Before coming with Europe 2020 action plans in a Society that has lost its habits and capacity for self-governance and its appetite for change and innovation, it is important to adapt such action plans and take the right measures to re-build the necessary social bonds that will accept and implement the action plans.

Along the recent developments in anthropology research (e.g., the concept of "community of practice", coined by Wenger [13]), one can say that there is a lot of work to do in the field of re-structuring Romanian communities, in transforming them in live, dynamic, fullfledged organisms, aware of their capabilities and potential, ready to take action, to aggregate in communities of practice rather than of interest. This takes time and dedication.

\section{Knowledge-based development of small communities}

Development or growth?

While the Europe 2020 document includes in its title the term "growth", the term "development" would probably be more appropriate. The Strategy itself uses both terms: "sustainable growth" (starting with its title) and "sustainable development" [3, page 20] without making any difference and this can generate confusion. 
Attaining a level of personal satisfaction and well-being does not necessarily reduce to growth and in many cases it does not imply growth at all. Development is a systemic policy intervention aiming at the economic, cultural, health, security and social well-being of people. Growth is connected mainly to market productivity and rise in GDP, being only one aspect of the process of economic development [14].

The findings of recent EU documents on sustainable consumption $[15,25]$ are relevant for the matter:

- An average European citizen uses about four times more resources than one in Africa and three times more than one in Asia (but half of one in USA, Canada or Australia).

- $\quad$ Resource use per person increased by $9.1 \%$ in the EU-27 between 2000 and 2007, reaching some 17 tonnes per person annually. Of the 8.2 billion tonnes of materials used in the EU in 2007, minerals and metals accounted for more than $50 \%$, while fossil fuels and biomass were approximately $25 \%$ each.

- $\quad 87 \%$ of EU citizens agree that Europe could use its natural resources more efficiently, and $41 \%$ think that their household produces too much waste.

- The average floor area of dwellings increased from 81 to $87 \mathrm{~m}^{2}$ since 1990, while the number of people per household decreased from 2.8 to 2.4 .

- Europeans travel more kilometres by car. Although cars on average become more fuelefficient, overall fuel consumption for private cars does barely go down, mainly because more kilometres are driven (rebound effects).

- $\quad$ An estimated 89 million tonnes of food ends up as waste each year in the EU (180 kg per citizen).

- In 2008, every citizen on average threw out $444 \mathrm{~kg}$ of household waste, and indirectly generated 5.2 tonnes of waste in the European economy.

It is hard to believe that the economic growth could be the solution to these facts. Using fewer resources, generating less waste, travelling less, building smaller houses, throwing away less food will not prompt up the growth of production in the corresponding industrial sectors. Even increasing the amount of recycled waste is not the right solution because the main problem is not to generate the same amount of waste and recycle as much as possible of it but generating less and less waste in the first place.

What EU should look for is a new state of mind that accepts that well-being does not mean growth in production and associated consumerism but longer-lasting appliances, repair services, less owning, more sharing options. Some of these options are unacceptable connotations of well-being, nowadays. Abundance, maybe - waste, no thanks!

The conclusion is that the term "growth" should be better defined or replaced by a more appropriate term (development).

The driving force for sustainable progress being the present distance of the Romanian Society to the correct and inspiring objectives included in the Lisbon and Europe 2020 Strategies (conveniently updated, as already discussed), the present study will detail a practitioner view, a modus operandi that will try to translate them in practice in a way that 
could inspire other practitioners and, perhaps, will suggest some modification of the Europe 2020 Strategy that refers explicitly to its operational implementation. Most documents and studies addressing KBD refers to where knowledge is supposed to be concentrated, (academic media, renown universities, large IT companies, laboratories for nanotechnologies, nuclear physics, space technology, large urban areas, etc.). It seems there is a gap between these entities and the communities, especially small communities. Knowledge seems to flow from the large knowledge generating structures mentioned above toward the rest of the society that has only to wait and enjoy the results of scientific studies and experiments carried out in R\&D entities.

The authors believe that:

- There is a huge heritage and dowry of knowledge accumulated at small communities level. Human kind has progressed based on the findings of humble inventors lost in small communities;

- Pretending that small communities have to wait and apply what comes from R\&D Institutes denies the potential of generating valuable knowledge by everyone;

- People believe in their own ideas and experience. Encouraging the generation of such ideas, collecting and disseminating such experience will add to the well-being of small communities even if those new ideas have little or no connections with space technology, nanoparticles or advanced ultrapure materials;

- Neglecting the know-how accumulated by small communities in their historical development in trying to implement the Europe 2020 Strategy would be a recipe for failure. Small communities know better what is good for them, are already adapted and react swiftly to emergencies, know how to build good, inexpensive houses, how to reuse materials, how to spare energy, how to manage local resources to enjoy them the next year too, etc.;

- The simple fact that a commune or a village exists since the $12^{\text {th }}$ or $15^{\text {th }}$ Century constitutes the most severe performance indicator and certificate for sustainability and defies any other $21^{\text {st }}$ century metrics. All other levels of society, up to national government and EU structures have a lot to learn from the knowledge and life experience collected in small communities about how they managed to persist against all odds;

- Sustainable development must not deny, destroy what already exists and replace it with expedients and substitutes generated in some R\&D facility or in EU ad-hoc Agencies but must build on what proved to be right and durable in every community;

- Inspiring solutions for the current economic crisis are certainly to be found by studying small communities;

- What Europe 2020 could add to what communities already know and are familiar too is the dimension of swifter change and introduction of modern trends and tools of science and technology to their existing way of life.

An adapted definition of sustainability, on what small communities have lived for centuries may be derived from the well-known Brundtland Report, could be: "Sustainable development is development that meets the community needs of the present without 
compromising the ability of future generations and of neighbouring communities to meet their own needs".

History and the present time is full of examples of small, powerful communities across Europe and in the Mediterranean space that sustain the remarks above, not only for entire entities (villages, communes, cities) but also for segments of larger cities [16]. Large EUfinanced Projects are also directed to evaluate and build upon the know-how of small communities in managing a valuable resource like water, in Northern Africa [17].

A constructive study dedicated to what is the level of preparation of Croatia to align to the knowledge-based society [18], as illustrated in the new EU documents gives a very comprehensive definition of knowledge-based economy:

"A knowledge-based economy is one in which the generation and exploitation of knowledge play the predominant part in the creation of wealth. A knowledge economy is not an economy of scarcity, but rather of abundance because information and knowledge can be shared, and actually grow through application. A key component in a knowledge-based economy is human capital, or, more accurately, its competencies. In traditional industries most jobs require employees to learn how to perform routine functions, which, for the most part, remain constant over time. In the knowledge-based economy, rapid changes force workers constantly to acquire new skills and to update their skills throughout their lifetimes".

Knowledge translated in: applications, information, human capital, competencies wherever these keywords characterize a community, there are good premises for well-being.

An interesting experience in how to develop a sustainable strategy for a local community [19], as a primary tool for common action, provides a number of questions discussed by local people, questions that give substance to the concept of knowledge-based approach:

- What is good about living in this area (Chichester, UK)?

- What would you like to improve in the area?

- Taking away the limitations that exist. What would be your ideal vision of your area?

- Bringing limitations back into play, what priorities would you see for your area?

Evaluating the experience of the mentioned communities in EU as well as from other part of the world $[5,6,20]$ led to a handful of results expected by local people from knowledgebased development of their small communities:

1. Integrated communal services (water, sanitation, IT, cable TV, good education, health assistance, transportation, etc.), dependable and of high quality, acting proactively toward prevention of risk materialization by using communication, by protecting vulnerable people;

2. Sustainability, environmentally sound development, job creation inside the community;

3. Increase in the quality of life should maintain, preserve and develop the local specific that differentiates a given community from its neighbours;

4. An increased decision power and more resources allocated to communities. People want to take their fate in their own hands. 
In Romania, a recent study addresses the possibilities of knowledge-based development at the strategic level [21]:

1. Top-down strategies that neglect the feelings and specific wishes of the subjects;

2. Expert strategies, generating purely technical solutions, identified by experts for given areas and communities;

3. Bargaining strategies, based upon negotiations, compromise among all stakeholders. This category includes the "bottom-up approach" by which local decision makers identify problems and barriers, call for consultations among all community members, collect ideas and solutions and decide which are the best ones by the same mechanism of bargaining;

4. Heuristic strategies, having a high degree of rational and affective content. They come out from dialogue, participation, in the presence of experts, with community members. Community members will feel that they themselves have discovered the right solutions to their own problems;

5. Participatory strategies, based essentially on voting. The obvious disadvantages are that in small communities, this voting process can be easily manipulated and that not all the members of the same community have the same education and can discern and choose the right option.

A mix of these approaches, adapted to a given community and a given business and cultural environment will probably be the best solution for a given case. The present study will use mainly the bargaining approach, with some help from the experts' and heuristic strategies.

\section{Fundamental principles}

In putting local know-how and expertise to work for the benefits of the community itself, the following principles should be observed:

1. Equity in distributing profits and benefits generated by the knowledge-based development. A special code of good practices should be in operation at EU level to encourage and motivate innovative producers in small communities;

2. The depositary of traditional know-how may be individuals or groups. They should be fairly acknowledged and rewarded;

3. The knowledge heritage of a community is dynamic, upgrading, adapting. This will help implementing rapid changes required by the Europe 2020 strategy. Yet changes should be understood and accepted by the community, before being implemented. This approach would be applied to tangible matters (local products, handicrafts) and to intangibles (habits, healthy life, institutions, attitude toward deviants, etc.);

4. Whenever possible, know-how and expertise of local people should be protected by patents or trade-marks;

5. The mechanism for transmitting knowledge and expertise to future generations should be improved and institutionalized. Good practices generated in a community should be disseminated. Elderly people, known for their skills, should be able to transfer their know-how to younger generations, e.g., in schools; 
6. Feedback: all applications, improvements, adaptations of techniques and products inspired from the know-how of a community should come back and be presented to the same community;

7. Implementing knowledge-based development in small communities is a multidisciplinary endeavour; all the work needed will be carried out by a team of engineers, economists, ecologists, analysts with many years of experience in as many as diverse projects as possible.

\section{Sources of sustainable knowledge based development}

The study examined five sources of sustainable, knowledge-based development of small communities (subsequently detailed din Table 1):

- Material and energy resources of the community;

- The human factor;

- Intangibles active in the communities;

- The environment;

- $\quad$ An articulated, sustainable strategy.

Table 1 details also what could be the contribution of supplementary R\&D work in order to assess and certify that traditional materials, products, techniques are in line with current environmental, health and safety or other similar regulations.

\begin{tabular}{|c|c|c|c|}
\hline Category & Details & Contribution of $R \& D$ work & Remarks \\
\hline \multicolumn{4}{|c|}{ Material and Energy Resources } \\
\hline $\begin{array}{l}\text { Crafts, adding value } \\
\text { to local materials } \\
\text { and products }\end{array}$ & $\begin{array}{l}\text { New life to traditional skills } \\
\text { (glass, leather, wood } \\
\text { processing, painting, } \\
\text { engraving, sculpture, } \\
\text { dwelling, etc.) and use of local } \\
\text { ceramic ware, traditional } \\
\text { tableware, textiles and } \\
\text { clothing, etc. } \\
\text { Reviving the production and } \\
\text { processing of flax, hemp, silk. } \\
\text { Traditional dyes, detergents, } \\
\text { chemical mixtures, drugs from } \\
\text { plants, etc. }\end{array}$ & $\begin{array}{l}\text { Characterization of materials } \\
\text { and processes against } \\
\text { present EU health and safety } \\
\text { standards. Material, energy } \\
\text { balances for processes, } \\
\text { comparison to BAT. } \\
\text { Suggestions for using } \\
\text { renewables. } \\
\text { Evaluate the waste } \\
\text { generation processes and } \\
\text { methods for waste use and } \\
\text { disposal. }\end{array}$ & $\begin{array}{l}\text { Traditional products still } \\
\text { constitute curiosities at } \\
\text { national or international } \\
\text { fairs. Communication and } \\
\text { dissemination will help } \\
\text { their spreading, export. } \\
\text { RISK: traditional industry } \\
\text { could use newer, } \\
\text { environmentally } \\
\text { aggressive but more } \\
\text { profitable techniques } \\
\text { (electroplating, synthetic } \\
\text { dyes, etc.) }\end{array}$ \\
\hline $\begin{array}{l}\text { Traditional farming } \\
\text { and animal } \\
\text { breeding }\end{array}$ & $\begin{array}{l}\text { Identification of traditional } \\
\text { methods in agriculture and } \\
\text { animal farming } \\
\text { Identify plants that do not } \\
\text { need fertilizers and pesticides. } \\
\text { Respecting the traditional } \\
\text { calendar of agricultural works. } \\
\text { Traditional methods for plant } \\
\text { and animal protection. }\end{array}$ & $\begin{array}{l}\text { Comparing the traditional } \\
\text { approach to the principles of } \\
\text { ecology, accepted by EU. } \\
\text { Help and train local people } \\
\text { and business to access EU } \\
\text { funds }\end{array}$ & $\begin{array}{l}\text { Codes of practices needed } \\
\text { at EU level to protect and } \\
\text { promote traditional } \\
\text { agriculture and animal } \\
\text { breeding, targeting SMEs } \\
\text { and small communities, to } \\
\text { develop bio-economy } \\
\text { methods. }\end{array}$ \\
\hline
\end{tabular}




\begin{tabular}{|c|c|c|c|}
\hline Category & Details & Contribution of R\&D work & Remarks \\
\hline Diet & $\begin{array}{l}\text { Traditional diets, food and } \\
\text { drinks }\end{array}$ & $\begin{array}{l}\text { Analysis of products and } \\
\text { scientific evaluation of diet. } \\
\text { Comparison to quality } \\
\text { standards required in EU. } \\
\text { Encourage and support local } \\
\text { community to acquire ISO, } \\
\text { HACCP certifications and } \\
\text { register their trade-marks. }\end{array}$ & $\begin{array}{l}\text { Traditionally, food and } \\
\text { drinks are produced by } \\
\text { bio-techniques with no } \\
\text { chemicals or additives. } \\
\text { Promoting and } \\
\text { disseminating activities } \\
\text { needed }\end{array}$ \\
\hline $\begin{array}{l}\text { Tourism, commerce, } \\
\text { other services }\end{array}$ & $\begin{array}{l}\text { Pensions, hotels conserving } \\
\text { the local specific. } \\
\text { Gaming and fishing. } \\
\text { Traditional occupations could } \\
\text { serve to develop new sport } \\
\text { activities (river rafting } \\
\text { supervised by local people that } \\
\text { usually take the timber down } \\
\text { the rivers) }\end{array}$ & $\begin{array}{l}\text { Services at EU levels of } \\
\text { quality standards. } \\
\text { Encourage local owners to } \\
\text { apply for certification, } \\
\text { quality auditing, etc. }\end{array}$ & $\begin{array}{l}\text { Encourage associations. } \\
\text { Local, foreign language } \\
\text { speaking guides for } \\
\text { tourists needed. }\end{array}$ \\
\hline $\begin{array}{l}\text { Traditional } \\
\text { buildings and } \\
\text { households }\end{array}$ & $\begin{array}{l}\text { Techniques for increasing the } \\
\text { energy efficiency. Arranging } \\
\text { households along traditional } \\
\text { experience and habits. } \\
\text { Respecting the specific local } \\
\text { architecture. }\end{array}$ & $\begin{array}{l}\text { Evaluating energy efficiency } \\
\text { and environmental } \\
\text { footprints (Life Cycle } \\
\text { Assessment, [26]). }\end{array}$ & $\begin{array}{l}\text { Preserving what } \\
\text { differentiates a } \\
\text { community from its } \\
\text { neighbours }\end{array}$ \\
\hline Water management & $\begin{array}{l}\text { Identification of traditional } \\
\text { water sources, water } \\
\text { management techniques } \\
\text { leading to the protection of } \\
\text { rivers, lakes, underground } \\
\text { water. }\end{array}$ & $\begin{array}{l}\text { Water quality analyses. } \\
\text { Solutions for wastewater } \\
\text { treatment and sanitation. } \\
\text { Evaluating the potential of } \\
\text { recycling wastewater. }\end{array}$ & $\begin{array}{l}\text { The Water Framework } \\
\text { Directive [22] and lessons } \\
\text { learned from the EU Zer0 } \\
\text { Project [17] should be } \\
\text { carefully observed. }\end{array}$ \\
\hline $\begin{array}{l}\text { Energy } \\
\text { management }\end{array}$ & $\begin{array}{l}\text { Small communities could } \\
\text { become self-sufficient } \\
\text { energetically. }\end{array}$ & $\begin{array}{l}\text { Identification of solutions } \\
\text { for producing and saving } \\
\text { energy }\end{array}$ & $\begin{array}{l}\text { Larger projects (e.g., wind } \\
\text { turbines or micro- } \\
\text { hydropower stations) } \\
\text { could ask for more than } \\
\text { one community to be } \\
\text { implemented }\end{array}$ \\
\hline \multicolumn{4}{|l|}{ The Human Factor } \\
\hline Health & $\begin{array}{l}\text { Traditional medicine, } \\
\text { practices, drugs }\end{array}$ & $\begin{array}{l}\text { Scientifically assess the } \\
\text { efficiency and risk of } \\
\text { practices and drugs }\end{array}$ & $\begin{array}{l}\text { Intellectual protection of } \\
\text { products }\end{array}$ \\
\hline Education & $\begin{array}{l}\text { Complementary to schools, } \\
\text { communities should transfer } \\
\text { know-how and experience } \\
\text { through traditional methods } \\
\text { (apprenticeship, social } \\
\text { events, fairs, Sunday schools } \\
\text { in churches, etc.) }\end{array}$ & Assessing curriculum. & $\begin{array}{l}\text { Mobilizing local learned } \\
\text { people in the educational } \\
\text { process. Kindergartens } \\
\text { managed with the aid of } \\
\text { elderly, educated people. }\end{array}$ \\
\hline
\end{tabular}




\begin{tabular}{|c|c|c|c|}
\hline Category & Details & Contribution of $R \& D$ work & Remarks \\
\hline \multicolumn{4}{|l|}{ INTANGIBLES } \\
\hline Cultural Heritage & $\begin{array}{l}\text { Habits, customs, religious and } \\
\text { other traditional holidays. } \\
\text { Conservation of institutions, } \\
\text { ethnographic particularities. }\end{array}$ & $\begin{array}{l}\text { Assessing the content of } \\
\text { such heritage elements and } \\
\text { keeping them clean from } \\
\text { influences that would } \\
\text { compromise their existence } \\
\text { and value. }\end{array}$ & $\begin{array}{l}\text { Reviving the authentic } \\
\text { traditions and culture. }\end{array}$ \\
\hline $\begin{array}{l}\text { Participation, } \\
\text { communication, } \\
\text { social inclusion and } \\
\text { cohesion }\end{array}$ & $\begin{array}{l}\text { Traditionally, an Elderly } \\
\text { Council, enjoying an intrinsic } \\
\text { legitimacy overviewed and } \\
\text { solved many conflict inside the } \\
\text { community. Community } \\
\text { Gatherings should be revived } \\
\text { and given decision power. }\end{array}$ & $\begin{array}{l}\text { Educated people from the } \\
\text { community (teachers, } \\
\text { doctors, priests, technicians, } \\
\text { other specialists) should } \\
\text { promote permanent } \\
\text { dialogue inside the } \\
\text { community. }\end{array}$ & $\begin{array}{l}\text { Sanctions issued by } \\
\text { communities should be } \\
\text { complementary and not } \\
\text { contradicting the legal } \\
\text { conviction. Search for pro- } \\
\text { active, preventing rather } \\
\text { than coercive initiatives } \\
\text { and actions }\end{array}$ \\
\hline IT, GSM, Cable TV & $\begin{array}{l}\text { Should not replace traditional } \\
\text { direct contact of people, social } \\
\text { events, gatherings, etc. }\end{array}$ & $\begin{array}{l}\text { Identifying and using local } \\
\text { skilled computer specialists } \\
\text { to devise tools for e- } \\
\text { governance. }\end{array}$ & $\begin{array}{l}\text { IT, GSM, Cable TV should } \\
\text { remain a valuable tool to } \\
\text { promote and develop local } \\
\text { specific }\end{array}$ \\
\hline \multicolumn{4}{|l|}{ Environment } \\
\hline $\begin{array}{l}\text { Environmental } \\
\text { Protection, } \\
\text { biodiversity, } \\
\text { climatic change }\end{array}$ & $\begin{array}{l}\text { Traditional methods for } \\
\text { sustainable management of } \\
\text { forests, pastures, rivers. } \\
\text { Evaluate traditional responses } \\
\text { to disasters. }\end{array}$ & $\begin{array}{l}\text { Help training local people. } \\
\text { Assess emergency plans for } \\
\text { environmental accidents. }\end{array}$ & $\begin{array}{l}\text { Encouraging local ideas } \\
\text { and solutions for zero- } \\
\text { waste communities }\end{array}$ \\
\hline Symbiosis & $\begin{array}{l}\text { Re-build traditional } \\
\text { connections for exchange of } \\
\text { materials, services, products, } \\
\text { expertise among all interested } \\
\text { stakeholders }\end{array}$ & $\begin{array}{l}\text { Solutions for turning waste } \\
\text { from local or adjacent } \\
\text { sources to valuable } \\
\text { resources }\end{array}$ & $\begin{array}{l}\text { Co-operation with other } \\
\text { communities to be } \\
\text { institutionalized }\end{array}$ \\
\hline \multicolumn{4}{|l|}{ Strategy and tools } \\
\hline Strategy & $\begin{array}{l}\text { Establish objectives, priorities } \\
\text { in accordance with the local } \\
\text { specific }\end{array}$ & $\begin{array}{l}\text { Transferring expertise for } \\
\text { strategic management. }\end{array}$ & $\begin{array}{l}\text { Strategy should be the } \\
\text { result of local people } \\
\text { initiatives. }\end{array}$ \\
\hline Institutions & $\begin{array}{l}\text { Guilds, religious } \\
\text { gatherings, } \\
\text { celebrations of some } \\
\text { agricultural events, etc., } \\
\text { should be complementary to } \\
\text { existing institutions }\end{array}$ & $\begin{array}{l}\text { Include them in the strategy; } \\
\text { make them contributors to } \\
\text { the social bond. }\end{array}$ & $\begin{array}{l}\text { Old institutions are } \\
\text { intrinsic sources of local } \\
\text { legitimacy and should be } \\
\text { used to govern local } \\
\text { communities }\end{array}$ \\
\hline Management & $\begin{array}{l}\text { Traditional methods for } \\
\text { consultation, option } \\
\text { generation, decision making. }\end{array}$ & Assess their efficiency. & $\begin{array}{l}\text { New managerial tools are } \\
\text { complementary to older } \\
\text { ones, familiar to local } \\
\text { people. }\end{array}$ \\
\hline
\end{tabular}

Table 1. Sources of sustainable, knowledge based development of small communities 


\section{Project vision and objectives}

The Project Vision was: "the identification of small communities needs for adding value to their human, material, scientific and cultural capital, in order to sustainably increase their quality of life, in harmony with the environment".

The operational objectives of the Project were:

1. Selecting the focal area, establish a Project Advisory Board (subsequently PAB) and carrying out a preliminary diagnostic, by using tools like SWOT, in the focal area;

2. Interactive generation of options for development;

3. Selecting a number of agreed projects that will demonstrate the advantages of the approach and the potential of knowledge-based development of the focal area;

4. Know-how transfer to the local people, complementary to what expertise is already present in the focal area. This led to the application of some modern tools for strategic management of small communities;

5. Evaluating, where possible, the success of the Project by comparison to national or EU practices, etc.

\section{The focal area}

The Focal Area of the Pilot Project covered the territory of several communes in the Suceava County, in the Northern part of Romania. Initially, the communes of Ilisesti and Balaceana were envisaged but, during the Project, it attracted a number of other communities in the same County that took part, more or less actively: Scheia, Ciprian Porumbescu, Veresti, and Stroiesti. Some of these communes have more than one village. The total number of inhabitants is estimated at 20000 .

Once some local projects started, their immediate success acted like attractors, like a critical mass for some more communes. So, at the end of the project, there were 11 communes involved and the number is increasing.

A Project Advisory Board was set up that included mayors of the above mentioned communes but also specialists and even a priest. The Project co-ordinator (INCD-ECOINDBucharest) underlined that the Project should and shall stay absolutely free of any political involvement or connotation. The role of the PAB was essentially a honorific one - members of the $\mathrm{PAB}$ were in no way remunerated for their participation but their contribution was essential because:

- $\quad$ PAB members know best what is good for the local communities;

- They are aware of the traditions, ethnography, particularities of the area, how to preserve them, how to take the most out of them;

- They know who are the best local specialists, skilled persons that could contribute to a given part of the project;

- They have the authority and legitimacy to guide and censor the Project team on its way.

- $\quad$ They constitute the element of continuity, after the Project ends. 
The stakeholders identified during the Project were:

- $\quad$ The Commune halls (mayors, top clerks);

- The Church;

- Teachers from the local schools and doctors from local hospitals;

- Bank subsidiaries present in the area that are in the first line of crediting local business for starting new projects;

- Successful businessmen

- $\quad$ Educated retired people.

The role of the Project coordinator was:

- $\quad$ to identify the focal area and to obtain the commitment of local policy makers;

- to carry out an in-depth diagnostic of the focal area;

- to process, together with local specialists the SWOT findings and to generate a structured list of development options aligned to what communities knows, needs, can do;

- to facilitate dialogue and contact among all stakeholders, to smoothen communication and solve conflicts, if need be;

- $\quad$ To develop some R\&D work (chemical analyses, balances, cost-benefit assessment, test techniques against BAT, evaluate potential use of waste, etc.).

\section{The SWOT analysis}

Contrary to what someone could expect from a local community, lost in a beautiful landscape in the rural area of Bucovina (the historical name of the region), there was no need for instructing local people in order to carry out a meticulous and painstaking SWOT analysis. Young educated people took part with great interest in the action and produced high value documents for the initial diagnostic of the area.

Table 2 illustrates the SWOT analysis of the Ilisesti commune as it came from the local specialists. Little intervention has been made (elimination of some repetition, reformulation of some findings). Most of the suggestions of this Table can be found in SWOT analyses conducted in other communities so Table 2 may be considered representative for what happens in all the focal area.

\begin{tabular}{|l|l|}
\hline \multicolumn{2}{|l|}{ Section 1: Agriculture, forests, rural development } \\
\hline Strengths & Weaknesses \\
\hline - Majority of population work in agriculture & - Poorly equipped farms; \\
- Large available areas of the commune enable & - No collecting and processing capacities for the \\
cultivation of an important number of plants & local products; \\
(wheat, maize, rye, potatoes, vegetables, & - No irrigation systems; \\
pastures, orchards); & - Insufficient development of service sector; \\
- Animal breeding has a long tradition; & - Farmers own very small pieces of land - \\
& cultures are fragmented; \\
& - No centres for artificial animal breeding; \\
\hline
\end{tabular}




\begin{tabular}{|c|c|}
\hline Opportunities & Threats \\
\hline $\begin{array}{l}\text { Room for association of local farmers in larger } \\
\text { organizations; } \\
\text { - EU funds available, with the support of the } \\
\text { local Agricultural Chamber; } \\
\text { - Potential for wind energy production to reduce } \\
\text { the energy bill of farmers; } \\
\text { - Large potential for bio-products. }\end{array}$ & $\begin{array}{l}\text { - Increased competition makes difficult the way } \\
\text { of local products to EU markets; } \\
\text { - Unpredictable, constantly changing legal } \\
\text { system; } \\
\text { - No protection / encouraging measures for } \\
\text { domestic agriculture, SMEs; } \\
\text { - Low awareness about EU norms and potential } \\
\text { cooperation; }\end{array}$ \\
\hline \multicolumn{2}{|l|}{ Section 2: Infrastructure and Environment } \\
\hline Strengths & Weaknesses \\
\hline $\begin{array}{l}\text { - } \text { Access to an important national road, DN17 } \\
\text { - } \\
\text { Fuel distribution capacities available for } \\
\text { domestic fuel and for cars; } \\
\text { - Existence of a human dispensary, a veterinary } \\
\text { clinic and a pharmacy; } \\
\text { - } \quad \text { Good quality timber and wooden products; } \\
\text { - } \quad \text { The largest (600000m3/yr) wooden waste- } \\
\text { processing facilities in the Northern part of } \\
\text { Romania are only } 40 \mathrm{~km} \text { away; } \\
\text { - } \quad \text { There is a wheat mill and a large bakery in the } \\
\text { commune; } \\
\text { - A state-of-the-art meat processing unit } \\
\text { operates in the commune; } \\
\text { - Relatively good quality, reliable INTERNET, } \\
\text { GSM and Cable TV networks. }\end{array}$ & $\begin{array}{l}\text { - No sewerage system and no wastewater } \\
\text { treatment facility; } \\
\text { - Natural gas network is not present in the area; } \\
\text { - } \quad \text { Road network need maintenance and repair; } \\
\text { - River pollution; } \\
\text { - } \quad \text { Little interest of local business for environment } \\
\text { protection; } \\
\text { - Environmental education - inadequate; } \\
\text { - } \quad \text { There is no eco-landfill available } \\
\text { - } \quad \text { Health infrastructure does not cover the local } \\
\text { needs; } \\
\text { - } \quad \text { Forests affected by irrational exploitation - led } \\
\text { - to landslides, floods; } \\
\text { - Large amounts of wooden waste pollutes } \\
\text { valleys, rivers, obstruct roads, cause floods; } \\
\text { - No domestic waste recycled. }\end{array}$ \\
\hline Opportunities & Threats \\
\hline $\begin{array}{l}\text { Installing a water supply system and investing } \\
\text { in sanitation and wastewater treatment; } \\
\text { - High potential for waste recycling. }\end{array}$ & $\begin{array}{l}\text { - Little experience in elaborating and } \\
\text { management of EU financed Projects; } \\
\text { - The zone is exposed to transboundary } \\
\text { pollution (Chernobyl). }\end{array}$ \\
\hline \multicolumn{2}{|l|}{ Section 3: Economic } \\
\hline Strengths & Weaknesses \\
\hline $\begin{array}{l}\text { - Area renown for good, diverse food, good } \\
\text { traditional cuisine } \\
\text { - Ecological products developing rapidly } \\
\text { - } \\
\text { Animal breeding offers large quantities of } \\
\text { animal products; } \\
\text { - } \text { Highly skilled workforce. }\end{array}$ & $\begin{array}{l}\text { - Inadequate infrastructure of food and drink } \\
\text { industry; } \\
\text { - No relevant foreign investments; } \\
\text { - Degradation of potential industrial sites, built } \\
\text { before 1990; } \\
\text { - } \quad \text { Little marketing activities }\end{array}$ \\
\hline Opportunities & Threats \\
\hline $\begin{array}{l}\text { The area is known as the land of potato. Could } \\
\text { become a source of ethanol, as car fuel } \\
\text { - Workshops and other infrastructure available } \\
\text { for industrial development. }\end{array}$ & $\begin{array}{l}\text { - The area is little known abroad, to foreign } \\
\text { investors; } \\
\text { - Little flexibility of local people to market needs; } \\
\text { - } \text { Increased share of undeclared work. }\end{array}$ \\
\hline
\end{tabular}




\begin{tabular}{|c|c|}
\hline \multicolumn{2}{|l|}{ Section 4: Tourism } \\
\hline Strengths & Weaknesses \\
\hline $\begin{array}{l}\text { - } \text { Large number of small pensions, hotels } \\
\text { - } \text { Good access to important monuments; } \\
\text { - } \text { Many protected areas; } \\
\text { - People renown for their hospitality } \\
\text { - Probably the only private ZOO in Romania }\end{array}$ & $\begin{array}{l}\text { - No funds for investment in touristic } \\
\text { infrastructure } \\
\text { - } \quad \text { No personnel for touristic activities } \\
\text { - } \quad \text { Little promotion of touristic potential } \\
\text { - }\end{array}$ \\
\hline Opportunities & Threats \\
\hline $\begin{array}{l}\text { New forms of relaxation (rafting, paragliding); } \\
\text { - Cultural tourism potential. }\end{array}$ & $\begin{array}{l}\text { - Investors prefer other areas (sea-side, higher } \\
\text { mountains); } \\
\text { - Limited marketing and promotion. }\end{array}$ \\
\hline \multicolumn{2}{|l|}{ Section 5: Education and Culture } \\
\hline Strengths & Weaknesses \\
\hline $\begin{array}{l}\text { The commune has a large school and a } \\
\text { kindergarten; } \\
\text { - A large public library; } \\
\text { - Many traditional cultural, religious events still } \\
\text { active; }\end{array}$ & $\begin{array}{l}\text { - The IT infrastructure in the school is } \\
\text { inadequate } \\
\text { - Many pupils leave school before completing } \\
\text { the } 8 \text { grade stage. }\end{array}$ \\
\hline Opportunities & Threats \\
\hline $\begin{array}{l}\text { School rehabilitation with EU funds; } \\
\text { - Motivating teachers to work for the commune, } \\
\text { not only in schools; }\end{array}$ & $\begin{array}{l}\text { Large number of families disrupted (father and } \\
\text { / or mother working abroad, leaves children to } \\
\text { grandparents' care); }\end{array}$ \\
\hline
\end{tabular}

Table 2. SWOT Analysis findings.

The conclusions of the first stage in the SWOT analysis are:

- There is a marked interest for the Project, illustrated by the celerity and level of detail of the SWOT submitted by local specialists to the Project Team;

- There are good traditions that must be revived so that they will contribute to social cohesion (farming, traditional food and drink, habits, fairs, etc.);

- Great potential for profiting from local resources;

- There is no coherent strategy for sustainable development in the focal area;

- Communities could become self-sufficient (energy, resources) and provide other regions with ethanol from potatoes, wind energy, traditional products;

- $\quad$ Little has been made to protect and promote local products;

- Great potential for improving communication, dialogue, decision making processes;

- The environment constitutes a big problem;

- There are social aspects that need special attention (early-leave of the educational system, separation of families and parents going to work abroad).

\section{Generating options for community development}

All the SWOT tables from the focal area were consolidated with the contribution of local specialists and PAB. In the process, some issues were dropped, some others were moved from one category to another, some others were rephrased. 
A single table resulted after intense interactive work and discussions. It was an excellent opportunity for the local specialists to meet and learn to work together for the benefit of the communities. This was one of the most important intangible benefits of the Project.

The SWOT Table was further re-organized in the following manner. First, local specialists were asked to give each SWOT finding 2 scores, in the interval $1-10$ :

- One that answers the question: "is the issue important for the local community?" $(1=$ least important; 10 = very important);

- The other, answering the question: "Have the local communities the capability and means to carry out the task of the SWOT issue?" $(1=$ no means available; $10=$ all required means are available).

Knowledge that came with the Project co-ordinator was included in this score.

An aggregate score has been subsequently derived, based on the two scores given to each SWOT finding, using the formula:

$$
\text { Aggregate Score }=\frac{2}{\frac{1}{\text { Score } 1}+\frac{1}{\text { Score } 2}}
$$

The resulted aggregate scores are in the same interval 1 (worse) - 10 (best). The formula, inspired from chemical engineering (series of resistances to heat or mass transfer) ensures that a SWOT finding will result highly opportune and feasible only if both Score 1 and Score 2 are high, because the aggregate score calculated with this formula is less than the lowest values of Score 1 and Score 2.

Using these aggregate scores, the SWOT findings, reformulated and detailed as options for local development during interactive analysis, were classified in 4 categories, in the same way the options for cleaner production are usually classified:

- A-type options that could be easily implemented in the short term and are relevant for the local communities

- B-type options, requiring some investment but being relevant for the community;

- C-type options, requiring large funding and large time horizon for implementation;

- $\quad$-type options, left aside for the time being.

These options are presented in Table 3. They are organized in 4 main chapters (infrastructure, profit generation, social cohesion, and institutional framework)

Table 3 includes some particularities:

- Local people know what they need and what could be the solutions for their problems;

- The concern of local specialists for energy and environment (core themes of any EU strategy) is obvious and well structured;

- Large number of business ideas shows that local people are at current with community potential, to sustainable products (e.g., ethanol for cars, collagen from bones, etc.). 


\begin{tabular}{|c|c|c|c|c|}
\hline & Infrastructure & $\begin{array}{c}\text { Profit generating } \\
\text { activities }\end{array}$ & Social Cohesion & $\begin{array}{c}\text { Institutional } \\
\text { framework }\end{array}$ \\
\hline $\begin{array}{l}\text { A } \\
\text { options }\end{array}$ & $\begin{array}{l}\text { Landscaping } \\
\text { Keep public spaces clean } \\
\text { and neat } \\
\text { River Banks } \\
\text { maintenance against } \\
\text { floods }\end{array}$ & 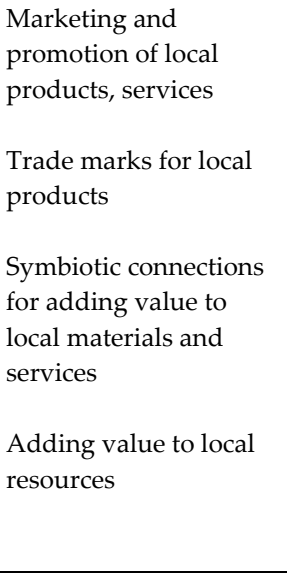 & $\begin{array}{l}\text { Local companies } \\
\text { should hire local } \\
\text { people first } \\
\text { Creating jobs for } \\
\text { people with } \\
\text { disabilities, elderly } \\
\text { Increase } \\
\text { environmental } \\
\text { awareness } \\
\text { Collecting facts and } \\
\text { objects illustrating } \\
\text { commune history } \\
\text { and specific }\end{array}$ & $\begin{array}{l}\text { Devising a Sustainable } \\
\text { Strategy } \\
\text { Cooperation with all } \\
\text { stakeholders, } \\
\text { neighbouring } \\
\text { communes } \\
\text { Assisting families } \\
\text { having members } \\
\text { working abroad } \\
\text { Church to become } \\
\text { involved in solving } \\
\text { social problems, fight } \\
\text { criminal behaviour }\end{array}$ \\
\hline $\begin{array}{l}\text { B } \\
\text { options }\end{array}$ & $\begin{array}{l}\text { Water supply network } \\
\text { Acquiring a special } \\
\text { bulldozer for cleaning } \\
\text { the snow on the roads } \\
\text { Upgrading the IT } \\
\text { infrastructure in schools, } \\
\text { kindergartens } \\
\text { Reforestation }\end{array}$ & $\begin{array}{l}\text { Promoting the use of } \\
\text { renewables as energy } \\
\text { sources } \\
\text { New processing } \\
\text { facilities for } \\
\text { agricultural and animal } \\
\text { products (traditional } \\
\text { products) } \\
\text { Waste recycling }\end{array}$ & $\begin{array}{l}\text { Expanding schools } \\
\text { Building a } \\
\text { retirement home } \\
\text { and a facility for } \\
\text { people with } \\
\text { disabilities } \\
\text { Educational } \\
\text { programmes for } \\
\text { adult and young } \\
\text { people }\end{array}$ & $\begin{array}{l}\text { Defining and } \\
\text { registering the BRAND } \\
\text { of the Commune } \\
\text { Lobby activities at local } \\
\text { and central level for } \\
\text { promoting interests of } \\
\text { communities. } \\
\text { Commune Meetings to } \\
\text { be revived and become } \\
\text { legitimate critics of the } \\
\text { local people }\end{array}$ \\
\hline $\begin{array}{l}\text { C } \\
\text { options }\end{array}$ & $\begin{array}{l}\text { Modernize the road } \\
\text { network } \\
\text { Large work along rivers } \\
\text { for protection against } \\
\text { floods } \\
\text { Wastewater treatment } \\
\text { station } \\
\text { Ecological landfill }\end{array}$ & $\begin{array}{l}\text { Add value to local } \\
\text { resources: Fruit } \\
\text { processing units, } \\
\text { brewery, and trout } \\
\text { breeding. } \\
\text { Produce / distribute } \\
\text { stoves, small scale } \\
\text { boilers operating on } \\
\text { wooden-chips. } \\
\text { Valuables from waste } \\
\text { (pet-food and collagen } \\
\text { from animal waste) } \\
\text { Incineration of waste } \\
\text { with energy recovery } \\
\text { and use in a } \\
\text { greenhouse }\end{array}$ & $\begin{array}{l}\text { Building a larger } \\
\text { kindergarten } \\
\text { Financial support } \\
\text { for young families } \\
\text { to build their } \\
\text { houses. }\end{array}$ & $\begin{array}{l}\text { Asking for the status of } \\
\text { town } \\
\text { Church and monasteries } \\
\text { to create housing } \\
\text { services for retired } \\
\text { people to live and work. }\end{array}$ \\
\hline
\end{tabular}




\begin{tabular}{|c|c|c|c|c|}
\hline & Infrastructure & $\begin{array}{l}\text { Profit generating } \\
\text { activities }\end{array}$ & Social Cohesion & $\begin{array}{c}\text { Institutional } \\
\text { framework }\end{array}$ \\
\hline $\begin{array}{l}\text { D } \\
\text { options }\end{array}$ & $\begin{array}{l}\text { Wind energy park } \\
\text { Micro hydropower } \\
\text { installations }\end{array}$ & $\begin{array}{l}\text { Ethanol from potatoes } \\
\text { Building a sport and } \\
\text { entertainment park }\end{array}$ & $\begin{array}{l}\text { Building a new } \\
\text { Commune centre, a } \\
\text { Museum of } \\
\text { ethnography }\end{array}$ & Local e-governance \\
\hline
\end{tabular}

Table 3. Classification of options for community development

- The concern of the same specialists about how to add value to local resources is also a noticeable. There are all kind of options (A, B, C, and D) for generating benefits from natural resources. This shows that the limiting step to the economic, sustainable development of the communities is not the lack of ideas or expertise but the funding and an encouraging business environment and an articulated marketing policy;

- There are some domains not covered by local specialists: marketing, economists familiar with EU funding, ecologists, etc. This should be a signal of concern for highschools and universities, to pay attention to real needs of communities and adapt their curricula accordingly;

- The social aspects are also important. Local communities understand the risks generated by parents leaving children and look abroad for work, the early leaving of schools or the increased number of criminal acts. Unfortunately, this constitutes a national concern as hundred of thousands of Romanians work abroad. There is no coherent approach to support families having 1-2 members far from home. The only good part of this situation is that these workers come home with a life experience, knowledge and some savings that could be of great help for the community;

- The institutional dimension is very well represented (Commune Meetings, Church to get more involved in the social life).

Based upon the mentioned aggregate scores, a short list of options emerged (Table 4).

\begin{tabular}{|c|l|c|l|}
\hline No. & \multicolumn{1}{|c|}{ Option } & Score & \multicolumn{1}{|c|}{ Remarks } \\
\hline 1. & $\begin{array}{l}\text { Devising the sustainable } \\
\text { strategy for the communes }\end{array}$ & 8.7 & $\begin{array}{l}\text { Helps local decision factors, specialists, SMEs to act coherently for } \\
\text { the good of all the community. }\end{array}$ \\
\hline 2. & $\begin{array}{l}\text { Promoting the use of } \\
\text { renewables as energy } \\
\text { sources }\end{array}$ & 8.4 & $\begin{array}{l}\text { In line with the 20/20/20 targets of EU. Tries to find knowledge- } \\
\text { based, efficient solutions to the energy sector, at the community } \\
\text { scale }\end{array}$ \\
\hline 3. & Recycling domestic waste & 8.1 & $\begin{array}{l}\text { Adds value to waste and implements the requirements of } \\
\text { development decoupled from the use of resources }\end{array}$ \\
\hline 4. & $\begin{array}{l}\text { Local companies should } \\
\text { hire local people first }\end{array}$ & 7.3 & Important social consequences \\
\hline 5. & $\begin{array}{l}\text { Increase environmental } \\
\text { awareness }\end{array}$ & 7.4 & $\begin{array}{l}\text { The SWOT has shown deficit in understanding and preventing } \\
\text { environmental aggression. }\end{array}$ \\
\hline 6. & $\begin{array}{l}\text { Assisting families having } \\
\text { members working abroad }\end{array}$ & 6.9 & A social problems for hundred of thousands of families in Romania \\
\hline 7. & $\begin{array}{l}\text { Trade marks for local } \\
\text { products }\end{array}$ & 6.8 & $\begin{array}{l}\text { Needs expertise and extended work for setting up the application } \\
\text { for the trade mark }\end{array}$ \\
\hline
\end{tabular}

Table 4. The shortlist of development options for local communities 


\section{Implementation of the selected options}

A-options have been adopted by local authorities and institutions and will be implemented in the near future. Their implementation does not need the help of the Project Coordinator.

The many business ideas (especially C-options) will constitute the priority for future business development in the area because they are generated and endorsed by local specialists and managers and, as the analyses carried out during the project, they are sustainable solutions for the problems in the communities. Working together for their implementation will test the value of the approach used to generate such options and confirm the importance of Wenger's "communities of practice" [13].

Option 5 needs a special training programme that will be devised by local specialists, teachers, retired experts, in order to identify and centralize all the environmental problems that confront each community, to analyze their consequences and to increase the awareness of local people. It is important that discussions should take place in the months to come with the County Environmental Protection Agency and the Local Environmental Guard.

Option 6 represents a very tough issue though its solution could be simple. Co-operation with County Authorities and with Child Protection Institutions is needed. Local families without children or single people have expressed their availability to take care of the children left alone by parents working in Spain, Italy or elsewhere but, though the problem is pressing (at national level several cases of suicides were recorded) all arrangements need a detailed case-by-case auditing and a formal, legal approval of child protection authorities.

Option 7 is the task of local experts that know best what differentiate local products from similar products of other areas.

In the subsequent paragraphs, the implementation of Options 1, 2, and 3 will be detailed.

\section{Sustainable community strategy}

The paragraph details how the sustainable strategy of local communities was set up during the Project.

In interacting with local experts and decision-making authorities, all the elements needed to set up a sustainable strategy for the community were detailed.

The building of the strategy started with adopting the Vision / Mission / Fundamental Values.

The Vision identifies what local authorities and stakeholders will value most about the community. Example of Vision phrases suggested to local authorities were:

- "our commune - history and tradition aligned to the $21^{\text {st }}$ Century"

- "experience Bucovina as it once was"

- "our commune lives by the legitimacy of history, the energy of its people and the beauty of the surrounding landscape" 
A Mission Statement defines what should be the community primary objective. Its prime function is internal and its prime audience, the community leaders and community representative people. The Mission Statement communicates what the local community represents and how would it contribute to its welfare.

Example: “We promote innovative and responsible initiatives that:

1. Will generate new economic opportunities based upon our heritage;

2. Will protect the environment for future generations;

3. Will encourage co-operation with our neighbours;

4. Will respect and value the dignity of elderly and helpless people.

The Fundamental Values of the Strategy (a "Constitution" of the commune) must come from what elderly people and PAB believe are the most important values (old, cherished, respected, shared by all)

The strategic objectives must come out from the SWOT and subsequent analyses and must be accepted by the majority of the local people.

Contribution and critics are more than welcome at this stage, in order to set up a list of objectives understood by all community representatives in the Project.

Strategic objectives must address the three pillars of sustainable development (economic, environmental, and social) and also be aligned to the 4 perspectives that constitute the horizon of local communities:

1. The Budget perspective;

2. The Stakeholders perspective;

3. The internal processes and capabilities perspective;

4. The learning and growth perspective.

These four perspectives have been taken from the celebrated Balanced Scorecard developed by Kaplan and Norton [24], completed to take into account the three pillars of sustainable development. Such an approach leads to a specific structure of the associated strategy map, illustrated in Table 5.

At the intersection of lines with columns one will find in each cell one or more strategic objectives for the sustainable development of the community. Table 5 already includes some examples of strategic objectives but the final ones will be devised by local communities, after intense consultation and interaction with the local people.

Arrows may be added to the map in Table 5, interconnecting objectives and showing how one issue determines the fulfilment of another.

Also, a system of classification can be adopted (e.g., 1 to 5 stars) and mentioned in the strategic map, denoting how important a strategic objective is.

It was stressed that the number of strategic objectives should be kept at a minimum possible (15-25). Of course, a community could have more than 25 objectives, addressing more 
specific matters but the majority of them could probably be added to the list of operational objectives.

\begin{tabular}{|c|c|c|c|c|}
\hline & \multicolumn{4}{|c|}{ Vision-Mission, Destination Statement } \\
\hline & Budget & $\begin{array}{l}\text { Adding value to } \\
\text { local resources } \\
\text { Absorbing EU and } \\
\text { similar funds }\end{array}$ & $\begin{array}{l}\text { Add value to traditional } \\
\text { habits, products, services, } \\
\text { landscape, historical heritage }\end{array}$ & $\begin{array}{l}\text { Benefits from waste } \\
\text { Green community }\end{array}$ \\
\hline \multirow{2}{*}{\multicolumn{2}{|c|}{$\begin{array}{l}\text { Internal } \\
\text { processes }\end{array}$}} & $\begin{array}{l}\text { Public-private } \\
\text { partnerships }\end{array}$ & $\begin{array}{c}\text { Business community to invest, } \\
\text { apply corporate social } \\
\text { responsibility }\end{array}$ & $\begin{array}{l}\text { Cooperation and } \\
\text { common, focused } \\
\text { action for a better } \\
\text { environment }\end{array}$ \\
\hline & & $\begin{array}{c}\text { Identify and } \\
\text { develop local } \\
\text { expertise } \\
\text { Motivate local } \\
\text { skilled people to } \\
\text { stay and work in } \\
\text { the community }\end{array}$ & $\begin{array}{l}\text { Conserving, reconstructing } \\
\text { the social bond } \\
\text { The Church to contribute to } \\
\text { reduce criminal deviances }\end{array}$ & $\begin{array}{l}\text { Decoupling } \\
\text { development from } \\
\text { resources. }\end{array}$ \\
\hline & $\begin{array}{c}\text { Learning } \mathcal{E} \\
\text { growth }\end{array}$ & $\begin{array}{l}\text { Continual } \\
\text { education. } \\
\text { e-Governance }\end{array}$ & $\begin{array}{c}\text { Support elderly, helpless, } \\
\text { people in need, children left } \\
\text { alone by parents gone to work } \\
\text { abroad }\end{array}$ & Awareness \\
\hline & & Economic & Social & Environmental \\
\hline & \multicolumn{4}{|c|}{3 pillars of sustainable development } \\
\hline
\end{tabular}

Table 5. Strategic map with examples of objectives for sustainable development.

Such a structure of the strategic map commits the experts and the policy makers at the community level to address all the essential aspects of their community, its structure, its connections, its capabilities and its future, but also the 3 factors that should be considered in any sustainable development process.

Once they chose to organize their strategic objectives in this way, these objectives must fill in every cell, in order to show the dedication of local decision makers to set up a comprehensive strategy that covers all the issues. Also, they must be relevant and make sense for the local people, answer to their expectations.

Filling in just a page, the map is a powerful vector for communicating the strategy, the intentions of local community representatives to all stakeholders, to all interested persons or organizations. It constitutes the most visible part of the strategy, submitted to public scrutiny.

Implementing the strategy calls for hard work directed to: 
- $\quad$ The setting up of clear-cut policies at community level;

- Detailed actions plans meant to identify and mobilize all resources needed in the accomplishment of a given strategic objective;

- Targets and deadlines for each objectives;

- Responsibilities for people that carry out the strategy implementation.

If need be, some of these elements could be confidential or made available to a limited number of people (e.g., stipulations of some public-private contracts).

Each strategic objective should be accompanied by one or more key performance indicators (KPIs).

Devising a list of KPIs constitutes the most difficult and delicate operation in the implementation of the strategy. They form the metrics of the strategy, the essential tools for evaluating how progress is made.

For a sound system of KPIs:

- They must completely characterize the strategic process and its evolution;

- $\quad$ There must be a balance between leading and lagging indicators [24];

- $\quad$ Some of the KPIs must be agreed with neighbouring communities (e.g., those referring to the management and exploitation of rivers, pastures, forests, other natural resources, waste);

- KPIs must be simple to derive and must be based, if possible, on existing metrics available at the community level;

- They must be easily understood by most people;

KPIs must be accompanied by transparent targets and deadlines in order to assess the progress or the flaws in the strategy.

Examples of KPIs:

- $\quad$ Income from tourism;

- Number of pupils that have left the educational system;

- $\quad$ Area of polluted environment reclaimed;

- Income from waste.

A final form of the community strategy will be produced by local authorities after consulting and interacting with all stakeholders.

\section{Promoting the use of renewables as energy sources}

The paragraph illustrates the implementation of one sustainable development option, based on local resources and expertise and addressing the energy domain. Forest people and timber producing companies in the Suceava County generate huge amounts of wooden waste (trunks with no economic value, branches, bark, and sawdust). The local Forest Authority asked for help from local companies to solve the problem of wooden waste left in forests, along the rivers, roads, etc. This waste currently alters the state of the local 
environment, obstructs streams and cause floods or landslides. The sawdust modifies the Carbon/Nitrogen balance in waters and soil and induces modifications in the microorganism population, alters the quality of surface and ground waters.

During the Project, an opportunity for funding was identified, from a Norwegian Fund. With Norwegian help, a local company acquired a second-hand truck with a special crane that collects wooden waste from remote places. Local specialists managed to repair the equipment and put it back in operation, in excellent conditions. Thus, local competences helped local company to expand and add value to waste, a rather new business in the area. In addition, it solves an important environmental problem and reinserts in the economic chain a valuable resource (firewood), saving important quantities of virgin resources (wood is the main source of energy for local communities).

Appreciations came from HE the Norwegian Ambassador in Romania who visited the area.

Table 6 centralizes the volume of wooden waste collected in 12 months.

\begin{tabular}{|c|c|}
\hline Jul 2010 & 451 \\
\hline Aug & 315 \\
\hline Sep & 544 \\
\hline Oct & 1004 \\
\hline Nov & 519 \\
\hline Dec & 437 \\
\hline Jan 2011 & 184 \\
\hline Feb & 381 \\
\hline Mar & 569 \\
\hline Apr & 290 \\
\hline May & 694 \\
\hline Jun & 271 \\
\hline Total Jul 2010-Jun 2011 & 5659 \\
\hline
\end{tabular}

Table 6. Wooden waste collected, $\mathrm{m}^{3}$ (July 2010 - June 2011).

The benefits generated by using wooden waste as fire wood or for producing briquettes from sawdust, at a local manufacturing unit are shown in Table 7.

Biomass as a fuel is a sustainable solution for the energy balance of local communities.

\begin{tabular}{|l|c|c|}
\hline \multicolumn{1}{|c|}{ Characteristics } & Value & Units \\
\hline Total biomass collected & 4527.2 & Tons \\
\hline Virgin resources saved (forests) & 26 & $\mathrm{ha}$ \\
\hline Main briquette characteristics: Higher Calorific Value & 4443 & $\mathrm{kcal} / \mathrm{kg}$ \\
\hline VOC content & 80.3 & $\mathrm{~g} / \mathrm{kg}$ \\
\hline Sulphur & 0.02 & $\mathrm{~g} / \mathrm{kg}$ \\
\hline Ash (may be used as fertilizer) & 0.43 & $\mathrm{~g} / \mathrm{kg}$ \\
\hline Fossil fuel replaced (spared): Methane & 536 & Tons \\
\hline
\end{tabular}


Sustainable Development - Authoritative and Leading Edge Content for Environmental Management

\begin{tabular}{|l|c|c|}
\hline \multicolumn{1}{|c|}{ Characteristics } & Value & Units \\
\hline Lignite (1.5\%S; 25\% Ash) & 1184 & Tons \\
\hline Fuel oil & 688 & Tons \\
\hline $\begin{array}{l}\text { Benign } \mathrm{CO}_{2} \text { generated by burning 4527.2 tons biomass replaces the } \mathrm{CO}_{2} \\
\text { generated by the following amounts of fossil fuels: Methane }\end{array}$ & 1524.31 & Tons \\
\hline coal (lignite) & 3352.39 & Tons \\
\hline fuel oil & 1946.7 & Tons \\
\hline SOx from 4527.2 tons biomass & 0.064 & Tons \\
\hline SOx from equivalent coal (lignite) & 35.52 & Tons \\
\hline SOx from equivalent fuel oil (0.5\% S) & 6.88 & Tons \\
\hline Ash from equivalent lignite (to landfill) & 296 & Tons \\
\hline Ash from equivalent fuel oil (to landfill) & 13.76 & Tons \\
\hline Social benefits: Jobs created & 26 & \\
\hline Cost of 1 Gcal produced by burning biomass & 50 & Euro \\
\hline Cost of 1 Gcal produced in power plants and delivered in the heating system & $60-150$ & Euro \\
\hline
\end{tabular}

Table 7. Benefits of wooden waste reinsertion in the economic cycle.

\section{Recycling domestic waste}

In Romania, only some $1 \%$ of the collected domestic waste is recycled (compare to EU level: 25$28 \%$ ). The paragraph illustrates how a sensitive issue was sorted out during the Project, based on local ideas, resources and expertize. During the implementation phase of the Project, a second-hand waste sorting station (manufactured in 1980) and a baler were identified and bought by a local company. The equipment needed capital repair and maintenance to become operational again but this was done by using the skills and ability of local specialists. It is worth noting that the mentioned equipment was the first of its kind in the area but repairing and maintaining has been carried out smoothly by local skilled technicians. Using the sorting station and the baler, domestic waste collected from the focal area ( 6 communes in the initial phase, 11 communes at the end of the Project) was sorted and prepared to be taken by recyclers.

Detailed discussions with local managers led to a modern solution of "upcycling" some of the waste (PET bottles) to fibres, instead of "downcycling" (incineration or conversion to lower quality goods).

Table 8 presents the benefits of recycling the domestic waste, in a public-private partnership, a novel approach for the focal area but a sound option in the view of the Europe 2020 strategy.

Table 9 shows the amounts of waste sent to recyclers in the first half of 2011.

The efforts of identifying funds, equipment, retrofitting it, starting a new business are rewarding, as Table 9 illustrates.

In addition, a simple benchmarking operation pointed out that the recycling rate of domestic waste in the focal area was not $15 \%$ but increased steadily and attained a $35 \%$ 
figure in August 2012, 35 times more than the national recycling rate (1\%). Currently, monthly recycling rates are $30-34 \%$.

\begin{tabular}{|l|l|}
\hline 6 communes (13 villages) in the focal area & $\begin{array}{l}\text { They produce approx } 2000 \mathrm{~m}^{3} / \mathrm{month} \text { domestic } \\
\text { waste. } \\
\text { At } 150 \mathrm{~kg} / \mathrm{m}^{3} \text { density, this means } 3600 \text { tons/yr }\end{array}$ \\
\hline $\begin{array}{l}\text { If } 15 \% \text { of the collected domestic waste is not } \\
\text { sorted and segregated, communities have to } \\
\text { pay } 1 \text { Euro/m }{ }^{3} \text { for the } 15 \% \text { share of the amount } \\
\text { of waste sent to landfill }\end{array}$ & \\
\hline $\begin{array}{l}\text { If minimum } 15 \% \text { of waste is sorted, 36000 Euro } \\
\text { taxes are not paid and remain in the } \\
\text { Community budget }\end{array}$ & $\begin{array}{l}\text { Sorted waste can be sold, leading to an income } \\
\text { of } 54000 \text { Euro/yr. } \\
\text { Communities save } 36000 \text { Euro taxes and earn } \\
54000 \text { Euro from selling sorted waste = } \\
9000 \text { Euro/yr }\end{array}$ \\
\hline & $\begin{array}{l}\text { The local company that sorts and bales the } \\
\text { waste earns extra } 104000 \text { Euro/yr (300 Euro/ton } \\
\text { of baled waste). }\end{array}$ \\
\hline Environmental benefits & $\begin{array}{l}\text { At least } 540 \text { tons waste diverted from landfill } \\
\text { and reinserted in the value chain }\end{array}$ \\
\hline Social benefits & \begin{tabular}{l}
5 new jobs, healthier environment \\
\hline
\end{tabular} \\
\hline
\end{tabular}

Table 8. Benefits from recycling domestic waste.

\begin{tabular}{|c|c|c|c|c|c|l|}
\hline $\begin{array}{c}\text { Month } \\
\text { (2011) }\end{array}$ & $\begin{array}{c}\text { Cardboard } \\
\text { and paper }\end{array}$ & PET & $\begin{array}{c}\text { Plastic } \\
\text { sheet }\end{array}$ & Metal & TOTAL & Remarks \\
\hline Feb & 7360 & 16580 & & & 23940 & \\
\hline Mar & 4673 & 29290 & & 1420 & 35383 & Arrangements made with a metal recycler \\
\hline Apr & 6099 & 50680 & 2525 & 467 & 59771 & $\begin{array}{l}\text { A plastic sheet recycler was identified. More } \\
\text { added value to collected plastic }\end{array}$ \\
\hline May & 2420 & 55020 & 920 & 1470 & 59830 & $\begin{array}{l}\text { Starting with May 2011 PET are segregated in } \\
\text { white" and "coloured”, adding supplementary } \\
\text { value to PET waste collected }\end{array}$ \\
\hline Jun & 42760 & 57340 & 22462 & 4540 & 127102 & \\
\hline
\end{tabular}

Table 9. Waste sent to recyclers $(\mathrm{kg})$

Table 9 illustrates continual efforts by local specialists and managers to diversify, to identify new smart and simple sources for adding value to the collected waste. In some cases efforts are still on the way (e.g., glass, textiles) because either the recycling infrastructure in Romania cannot process some kind of waste, either the recycler is too far from the focal area (transportation costs are too high). This leaves the door open for local managers to start or expand their businesses, to value locally the recycled waste available. 


\section{Conclusions}

The study showed the great potential of small community development based upon ideas, skills and efforts of the same communities, without waiting for miracle panacea from Central Authorities.

Knowledge-based development means a lot more than looking for and implementing last minute cutting-edge technologies. It means working together with local people, evaluating their problems, looking for local, up-to-date, smart and efficient solutions that contribute to the well-being of communities. The role of external facilitators (the Project coordinator, in this study) is to provoke a substantial dialogue, to suggest possible solutions, to assess the efficiency of the solutions generated, to mobilize all local specialists, to help finding financial support, to smoothen communication and co-operation among stakeholders.

Apart of some material successes (35\% recycle rate of local domestic waste, 31 new jobs, more than 4500 tons of biomass reinserted in the value chain, saving the equivalent amounts of fossil fuels, etc.), the project generated the lines for future development of the communities:

- A structured sustainable strategy;

- The associated strategic management tools;

- A shortlist of business ideas and development options believed to the most relevant and most suitable for the resources and know-how existing in the area;

- A framework of cooperation and dialogue, essential for future replication.

The project underlined the need of meticulous, in-depth work and co-operation of all stakeholders, of all those called to implement the generous objectives like those in the Europe 2020 Strategy and proves that innovation should not be limited to high-speed, efficient electric cars, IT stuff or high-yield solar panels. The approach of implementing the Europe 2020 Strategy should also be innovative and original in what regards commitment, organization, resources used, and human touch.

\section{Author details}

Cristian Teodorescu, Lucian Constantin,

Margareta Nicolau, Aurelia Ballo and Cristiana Cosma

INCD-ECOIND, Sector 6, Bucharest, Romania

\section{References}

[1] The Lisbon Strategy (2000), available at http://europa.eu/legislation_summaries/education_training_youth/general_framework/ c10241_en.htm accessed March 5, 2012.

[2] Lisbon Strategy Evaluation Document Commission Staff Working Document (2010), Available at http://ec.europa.eu/europe2020/pdf/lisbon_strategy_evaluation_en.pdf , accessed March 5, 2012. 
[3] Europe 2020 (2010), A European Strategy for Smart, Sustainable and Inclusive Growth, Communication from the Commission. Available at http://eur-lex.europa.eu/LexUriServ/LexUriServ.do?uri=COM:2010:2020:FIN:EN:PDF ， accessed March 5, 2012.

[4] Carillo, F.J., Batre S., (2012), “Understanding and Measurement: Perspectives on the Evolution of Knowledge-Based Development", International Journal of KnowledgeBased Development, 3(1): 1-16.

[5] Tan Yigitcanlar (2011), “Position Paper: Redefining Knowledge-Based Urban Development", International Journal of Knowledge-Based Development, 2(4): 340-356.

[6] Shrestha, K.K. and Z. Mahjabeen (2011), "Civic Science, Community Participation and Planning for Knowledge-Based Development: Analysis of Sydney Metropolitan Strategy", International Journal of Knowledge-Based Development, 2(4): 412-432.

[7] Badenhorst, Anne and Charlotte Scarf (2011), "Local action to support knowledgebased development", International Journal of Knowledge-Based Development, 2(3): 316-333.

[8] Mansell, R. et al (1999), “Opportunities for Knowledge-Based Development: Capabilities, Infrastructure, Investment and Policy", Science and Public Policy, 26(2): 91-100.

[9] Metaxiotis, K et al., "Knowledge-Based Development for Cities and Societies: Integrated Multi-Level Approaches", IGI Global (2010). Online book chapters available at http://www.igi-global.com/book/knowledge-based-development-citiessocieties/37271\&f=e-book, accessed April 15, 2012.

[10] Bandyopadhyay, S.(2009), "Knowledge-Based Economic Development: Mass Media and the Weightless Economy", The Toyota Centre, Suntory and Toyota International Centres for Economics and Related Disciplines, London School of Economics, available at http://sticerd.lse.ac.uk/dps/darp/DARP74.pdf accessed April 15, 2012.

[11] Gudes, O. et al.(2011), “Using a Knowledge-Based Approach: the Way Healthy Communities Make Decisions", Queensland University of Technology, Brisbane, available at http://eprints.qut.edu.au/46539/1/KCWS_2011_Proceeding_Gudess.pdf , accessed April 15, 2012.

[12] Becca, A. et al (2006), "The New Fundamentals in Planning for Local Economic Development: Knowledge-Based Communities", Georgia Institute of Technology, available at http://www.pled.gatech.edu/pages/PLED_Report/2006/PLED_KnowledgeBased_Communities_-_Fall_2006.pdf, accessed April 15, 2012.

[13] Wenger, E., "Community of Practice - A Brief Introduction", available at http://www.ewenger.com/theory/index.htm , accessed April 15, 2012.

[14] Sen, A (1983), “Which Way Now?”, Economic Journal, Vol. 93(372): 745-762.

[15] "Our Common Future" (1987), available at http://www.un-documents.net/wcedocf.htm, accessed March 5, 2012.

[16] Harrow Core Strategy Preferred Options (2006), available at http://www2.harrow.gov.uk/mgConvert2PDF.aspx?ID=63118\&J=1 accessed March 5, 2012. 
[17] Zer0 (2009), EU Zero Outflow Community Project: http://www.zer0-m.org/ accessed March 5, 2012.

[18] Bejakovic, P (2005), “How Prepared is Croatia for a Knowledge Based Society" Zagreb.

[19] Chichester Sustainable Community Strategy, available at http://www.chichesterinpartnership.org.uk/index.cfm?articleid=9287, accessed March 5,2012

[20] Bhargava, P.M., (2009), “How to Make India a Knowledge Based Society?" Furqan College, Hyderabad.

[21] Moldoveanu, G. and Dobrin C.(2008), Theoretical and Empirical Researches in Urban Management, 3(7):1-10.

[22] The Water Framework Directive (2000), available at http://ec.europa.eu/environment/water/water-framework/index_en.html, accessed March 5, 2012

[23] Zer0 (2009), EU Zero Outflow Community Project: http://www.zer0-m.org/ accessed March 5, 2012.

[24] The Balanced Scorecard Institute (2012), http://www.balancedscorecard.org/ accessed March 5, 2012.

[25] Sustainable Consumption in a Time of Crisis (2012), http://www.clickgreen.org.uk/analysis/business-analysis/123320-europe-looks-to-breakcycle-of-unsustainable-consumption.html , Accessed March 17, 2012.

[26] Life Cycle Thinking and Assessment (2012), http://lct.jrc.ec.europa.eu/ accessed April 15,2012 